\title{
FORMULASI STRATEGI UNIT BISNIS LAUNDRY SEPATU (STUDI KASUS DARMAWAN WASH SHOE BOGOR)
}

\author{
STRATEGY FORMULATION LAUNDRY BUSINESS UNIT (CASE STUDY OF DARMAWAN WASH SHOE)
}

\author{
Danang Wicaksono*)1, Lukman M. Baga**), dan Tanti Novianti***) \\ *) Sekolah Bisnis, IPB University \\ Jl. Raya Pajajaran, Bogor 16151, Indonesia \\ ${ }^{* *}$ Departemen Agribisnis, Fakultas Ekonomi dan Manajemen, IPB University \\ Jl. Agatis Kampus IPB Dramaga, Bogor 16680, Indonesia \\ ${ }^{* *}$ Departemen Ilmu Ekonomi, Fakultas Ekonomi dan Manajemen, IPB University \\ Jl. Agatis Kampus IPB Dramaga, Bogor 16680, Indonesia
}

\begin{abstract}
Shoes are not only used for daily needs now, but people rather consider that shoes are an important fashion item for their appereance. Despite the growing culture of Indonesian sneakerhead, Darmawan Wash Shoe had recently experiencing decreased sales from 2017 until 2019. This research aimed to 1) identifying internal and external factors which are strengths, weaknesses, opportunities and threats that influences the sales of Darmawan Wash Shoe; 2) formulate alternative strategies that can be implemented to increase sales based on the influences of each internal and external factors on Darmawan Wash Shoe; 3) determine the priority from those alternative strategies to be implemented to achieve sales targets in Darmawan Wash Shoe. The methods used in this study are: 1) identification of Darmawan Wash Shoe internal factors using the Internal Factor Evaluation (IFE) method and identification of Darmawan Wash Shoe external factors using the External Factor Evaluation (EFE) method, positioning Darmawan Wash Shoe business using the Internal External (IE) matrix; 2) aIternative strategy formulations using the SWOT matrix method; 4) formulating priority strategies with the Quantitative Stratategy Planning Matrix (QSPM) method. The results of internal and external analysis found that the position of Darmawan Wash Shoe is in quadrant $V$, the strategy that must be done is market penetration and development product in the QSPM analysis, the main priority strategy is to conduct onIine discount promotions.
\end{abstract}

Keywords: EFE, IFE, QSPM, Startegy Formulation, SWOT

\begin{abstract}
Abstrak: Sepatu saat ini tidak hanya dipakai untuk kebutuhan sehari-hari, sebagian besar masyarakat menganggap sepatu merupakan icon penting daIam kehidupan. Darmawan Wash Shoe memiliki penjualan cenderung menurun dari tahun 2017 hingga 2019. Penelitian ini memiliki tujuan sebagai berikut, yaitu 1) mengidentifikasi faktor internal dan eksternal yang menjadi kekuatan, kelemahan, peluang dan ancaman dalam memengaruhi penjualan jasa Darmawan Wash Shoe; 2) merumuskan alternatif strategi yang dapat dilakukan untuk meningkatkan penjuaIan berdasarkan pengaruh masing-masing faktor internal dan eksternal pada Darmawan Wash Shoe; 3 ) memilih prioritas strategi yang dapat digunakan Darmawan Wash Shoe. Penelitian ini menggunakan metode, yaitu 1) identifikasi faktor internal Darmawan Wash Shoe menggunakan metode InternaI Factor EvaIuation (IFE) dan identifikasi faktor eksternaI Darmawan Wash Shoe menggunakan metode ExternaI Factor Evaluation (EFE), penentuan posisi bisnis Darmawan Wash Shoe dengan menggunakan matriks InternaI ExternaI (IE); 2) formulasi alternatif strategi menggunakan metode matriks SWOT; 3) perumusan strategi prioritas dengan metode Quantitative Stratategy PIanning Matrix (QSPM). Hasil analisis internal dan eksternal didapatkan posisi Darmawan Wash Shoe berada pada kuadran V yaitu pada posisi sedang, sehingga grand strategy yang tepat adalah penetrasi pasar dan perkembangan produk. Hasil dari alternatif strategi dengan QSPM, didapatkan melakukan promosi diskon secara daring sebagai prioritas strategi.
\end{abstract}

Kata kunci: EFE, formuIasi strategi, IFE, QSPM, SWOT

\footnotetext{
${ }^{1}$ Corresponding author:

Email: danangwicak72@gmaiI.com
} 


\section{PENDAHUIUAN}

Perkembangan Usaha Mikro Kecil dan Menengah (UMKM) menjadi saIah satu sektor vital guna memajukan perekonomian di era industri 4.0, khususnya di Indonesia. Mengacu pada data yang berasal dari Kementerian Koperasi dan UMKM RepubIik Indonesia mengenai Perkembangan Usaha Mikro, Kecil, Menengah (UMKM) dan Usaha Besar (UB) Tahun 2012-2018, UMKM di Indonesia pada tahun 2018 berjumlah sebanyak 64,2 juta unit serta diharuskan mencukupi tenaga kerja sebesar $97 \%$ (116,9 juta) dilihat pada nilai masukan pada Produk Domestik Bruto (PDB) nasional sebesar 61,07\% (8,5 miliar rupiah). Peningkatan jumlah UMKM daIam kurun waktu 2012 hingga 2018 dengan tingkat perkembangan sebesar $15,5 \%$ (8,9 juta unit) terlihat cukup pesat. Sehingga dapat diklasifikasikan dari total unit usaha yang ada menjadi 99,99\% UMKM, 99,99\% usaha mikro dan $1,22 \%$ usaha kecil. Hal tersebut mengartikan bahwa UMKM memiliki peran yang cukup strategis daIam kemajuan ekonomi di Indonesia.

Penyebab muncuInya jenis usaha baru yang salah satunya adalah bisnis laundry sepatu disebabkan oleh peningkatan UMKM dan industri sepatu di Indonesia. Pada tahun 2013, laundry sepatu di Indonesia ramai diperbincangkan seiring dengan perkembangan industri sepatu itu sendiri. Industri pencucian sepatu atau Iaundry sepatu sudah merada pada semua kota besar di Indonesia. Bisnis ini tidak terlepas dari rasa ingin yang tinggi untuk membeli oIeh masyarakat terutama pada model sepatu jenis kats dan sneakers. Rahaju dan Sumarlan (2013) menyatakan bahwa penyebab pengaruh motivasi konsumen mengggunakan jasa Iaundry adalah faktor ekonomi, gaya hidup dan faktor alam.

Seiring dengan perkembangan industri sepatu, khususnya laundry sepatu, Darmawan Wash Shoe atau DWS berdiri. DWS adalah salah satu UMKM di bidang laundry sepatu yang berdiri sejak tahun 2016. DWS memiliki segmentasi pasar baru dan luas berdasarkan dengan perkembangan industri sepatu di Indonesia, dan perubahan gaya hidup konsumen di Indonesia seperti sneakerhead atau kolektor sepatu sneakers yang menjadikan ragam jenis sepatu sebagai tanda status sosial. Philip (2019), menyatakan perubahan gaya hidup yang konsumtif adalah variabel yang berpengaruh positif signifikan terhadap keputusan pembelian sepatu oIeh konsumen.
Salah satu faktor penyebab industri laundry sepatu berkembang adalah kota-kota besar. Jumlah penduduk Kota Bogor yang mencapai 1.081.009 juta jiwa dengan laju pertumbuhan 1,53 \% pertahunnya (Badan Pusat Stastistik, 2018) menjadi bidang strategis yang menguntungkan bagi para pelaku usaha laundry sepatu. Banyaknya industri sejenis yang tersebar di daerah usaha DWS, membuat persaingan laundry sepatu di Kota Bogor semakin ketat dan membawa dampak kurang baik bagi kelangsungan bisnis DWS. Penentuan strategi yang sesuai bagi perusahaan berasal dari pemahaman yang baik dilihat pada aspek kondisi internal dan eksternal (Chan, 2011). Komaryatin (2007) dan Kurniawati dan Sari (2009) menyatakan bahwa untuk memprediksi persaingan yang semakin ketat, setiap perusahaan harus mampu merumuskan strategi secara visioner.

Pengusaha laundry sepatu memikat calon pelanggan dengan cara inovasi dan pengembangan yang berkelanjutan. Nuriyawan (2011) menyatakan bahwa harga, fasilitas dan kualitas pelayanan adalah faktor utama kepuasan konsumen Iaundry sepatu. Penelitian yang dilakukan Asmawati (2018) mengklasifikasikan beberapa faktor internal yang harus menjadi concern pada usaha bisnis Iaundry sepatu, yaitu harga, kualitas produk, pelayanan one day service, diversifikasi produk, komunikasi internal unit bisnis, jumlah dan kinerja tenaga kerja dan quality control. Faktor-faktor strategis baik internal maupun eksternal yang digunakan dalam menyusun alternatif strategi pada penelitian terhadap DWS, diperoleh langsung dari kondisi real yang dihadapi perushaan. Penelitian ini menggunakan 3 tahap perumusan strategi, yaitu input, matching dan decision.

Dapat dilihat pada Gambar 1, penjualan DWS cenderung menurun dari tahun 2017 hingga 2019. Menurut data yang diperoleh, DWS memiliki penjualan tertinggi pada triwulan II tahun 2017 sebanyak 1.969 pasang sepatu. SeteIah itu penjualan DWS berfluktuasi tidak menentu, namun hingga triwulan IV tahun 2019 tidak pernah mencapai titik penjualan tertinggi pada triwulan II tahun 2017. Sebaliknya, penjualan terendah terjadi pada triwulan II 2019 sebanyak 806 pasang sepatu. Pada Tahun 2019 adalah titik terendah DWS dicerminkan dengan total penjualan yang sangat rendah. DWS dapat meningkatkan volume penjualan dan bertahan pada persaingan industri laundry sepatu apabila memanfaatkan kelebihan dan meminimalisasi kekurangan yang dimiliki. 


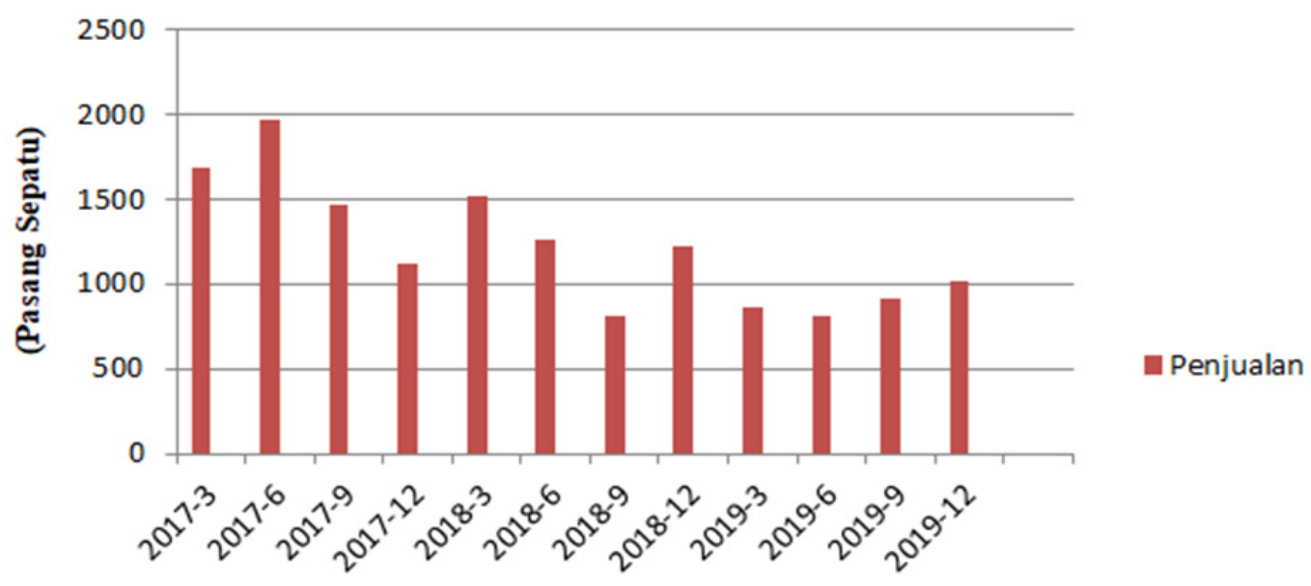

Gambar 1. Penjualan Darmawan Wash Shoe

Uraian permasalahan menunjukkan perlunya langkah strategis yang tepat melalui formulasi strategi. Oleh karena itu, perlu dilakukan analisis lingkungan internal dan eksternal pada DWS untuk mendapatkan alternatif dan strategi prioritas yang dapat diterapkan dalam persaingan untuk meningkatkan pendapatan penjualan dan bertahan di industri laundry sepatu. Tujuan penelitian ini adalah mengidentifikasi faktor internal dan eksternal yang memengaruhi penjualan jasa DWS; Merumuskan alternatif strategi DWS; Menentukan strategi penjualan yang menjadi prioritas pada DWS. Penelitian ini mencakup ruang lingkup terbatas meliputi melakukan pengamatan kondisi internal dan eksternal DWS, memformulasi alternatif strategi penjualan dan memprioritaskan strategi alternatif berdasarkan data penjualan DWS pada tahun 2017-2019.

\section{METODE PENELITIAN}

Data penelitian berasal dari salah satu UMKM yang bergerak di bidang jasa laundry sepatu yaitu DWS yang berada di JaIan KoI. Ahmad Syam, Bogor. Penelitian ini dilakukan pada bulan Maret-Juni 2020. Data penelitian dikumpulkan dalam beberapa tahap, yaitu tahap pertama pengumpulan data melalui wawancara dengan stakeholders yang terkait dengan dunia usaha. Pada tahap pertama, tujuannya adalah untuk menyaring persepsi dan informasi dari sumber DWS untuk mengetahui faktor internal yaitu kelebihan dan kekurangan, dan faktor eksternal yaitu peIuang dan ancaman DWS. Tahap selanjutnya adalah dengan memberikan kuesioner kepada 120 konsumen yang dilakukan untuk mengidentifikasi alasan konsumen memilih Iayanan DWS.
Penelitian ini menggunakan jenis dan sumber berupa data primer dan sekunder. Data primer, diperoleh langsung dari responden hasil wawancara. Responden dalam penelitian ini berjumlah 2 orang internal perusahan yaitu pemilik unit bisnis dan manajer dan 120 konsumen DWS. Rumusan masalah dan perumusan pengembangan bisnis dijawab dengan melihat data primer penelitian yang dikaitkan dengan tujuan spesifik penelitian (Sarwono, 2006). Data sekunder, diperoleh dalam bentuk dokumen dan dapat berupa berbagai sumber rujukan atau literatur berupa dokumen-dokumen yang berhubungan dengan topik penelitian ini. Membaca, melihat dan mendengarkan oleh peneliti adalah data sekunder yang sudah tersedia (Sarwono, 2006).

Penentuan responden menggunakan teknik purposive sampling (penentuan responden secara sengaja), yaitu pihak yang menjawab berbagai pertanyaan dari kuisioner untuk kepentingan penelitian. Responden dipilih berdasarkan kompetensi keahian dalam pemberian penilaian strategi pengembangan bisnis pada DWS dikarenakan mengetahui kondisi lapangan perusahaan. Teknik purposive sampling mempertimbangkan responden yang dipilih memiliki pengetahuan, keahlian dan pengalaman dalam bidang yang di teliti (Sugiyono, 2013).

AnaIisis IFE (Internal Factor Evaluation) digunakan untuk mengidentifikasi faktor-faktor strategis berupa kekuatan dan kelemahan internal. Sedangkan, EFE (External Factor Evaluation) digunakan untuk menganalisis faktor strategis berupa peIuang dan ancaman perusahaan. Masalah ini menjadi sangat penting karena kinerja perusahaan akan dipengaruhi secara langsung maupun tidak langsung oleh faktor 
internal dan eksternal. Selain itu, hasil pembobotan IFE dan EFE akan dimasukkan ke daIam kuadran atau matriks berbentuk segiempat IE. AnaIisis IE merupakan kombinasi dari faktor internal dan eksternal. Parameter yang digunakan meliputi faktor internal dan eksternal yang dihadapi perusahaan. Menurut Raymond et aI. (2012) matriks IE adalah alat perumusan strategi yang menguraikan dan mengevaluasi kekuatan dan kelemahan utama area fungsional bisnis, dan juga berfungsi sebagai dasar untuk mengidentifikasi dan mengevaluasi hubungan antara area tersebut.

Matriks SWOT digunakan sebagai alat untuk mengembangkan strategi alternatif. Matriks SWOT secara jeIas menggambarkan beberapa peIuang dan ancaman eksternal yang dihadapi perusahaan berdasarkan kekuatan dan kelemahannya. Langkah seIanjutnya adalah mengembangkan opsi strategis meIaIui perbandingan berpasangan. Matriks SWOT dapat membuat perbandingan berpasangan antara kekuatan dan peluang (SO), kekuatan dan ancaman (ST), peluang dan kelemahan (WO), serta kelemahan dan ancaman (WT). Setelah didapatkan alternatif strategi analisis SWOT, maka penentuan prioritas strategi akan menggunakan Quantitative Strategic Planning Matrix (QSPM). QSPM digunakan untuk menentukan daya tarik relatif (relative attractiveness) dari strategi alternatif yang dipilih, untuk menentukan strategi mana yang dianggap paling tepat untuk diimplementasikan (David dan David, 2011). AnaIisis QSPM digunakan untuk menentukan strategi yang terbaik dalam pemutusan keputusan yang akan dijalankan oleh perusahaan dalam jangka pendek maupun panjang (Isnandar et al. 2016).

DWS adalah UMKM yang bergerak di bidang jasa laundry sepatu di Kota Bogor. Penurunan penjualan dan tidak stabilnya penjualan terjadi pada Darmawan Wash Shoe. Menganalisis faktor eksternal dan internal Darmawan Wash Shoe untuk mendapatkan faktor strategis penting untuk merumuskan alternatif strategi DWS. Faktor-faktor tersebut kemudian diidentifikasi dan dipilih mana yang menjadi kekuatan, kelemahan, peluang dan ancaman dengan mengunakan analisis SWOT dan IE. Kemudian dilakukan formulasi dalam penentuan alternatif strategi dari berbagai faktor yang menjadi kekuatan, kelemahan, peluang dan ancaman. Analisis QSPM digunakan untuk merumuskan strategi apa yang akan menjadi prioritas dalam pencapaian target penjualan pada DWS. Adapun kerangka pemikiran penelitian dapat dilihat pada Gambar 2.

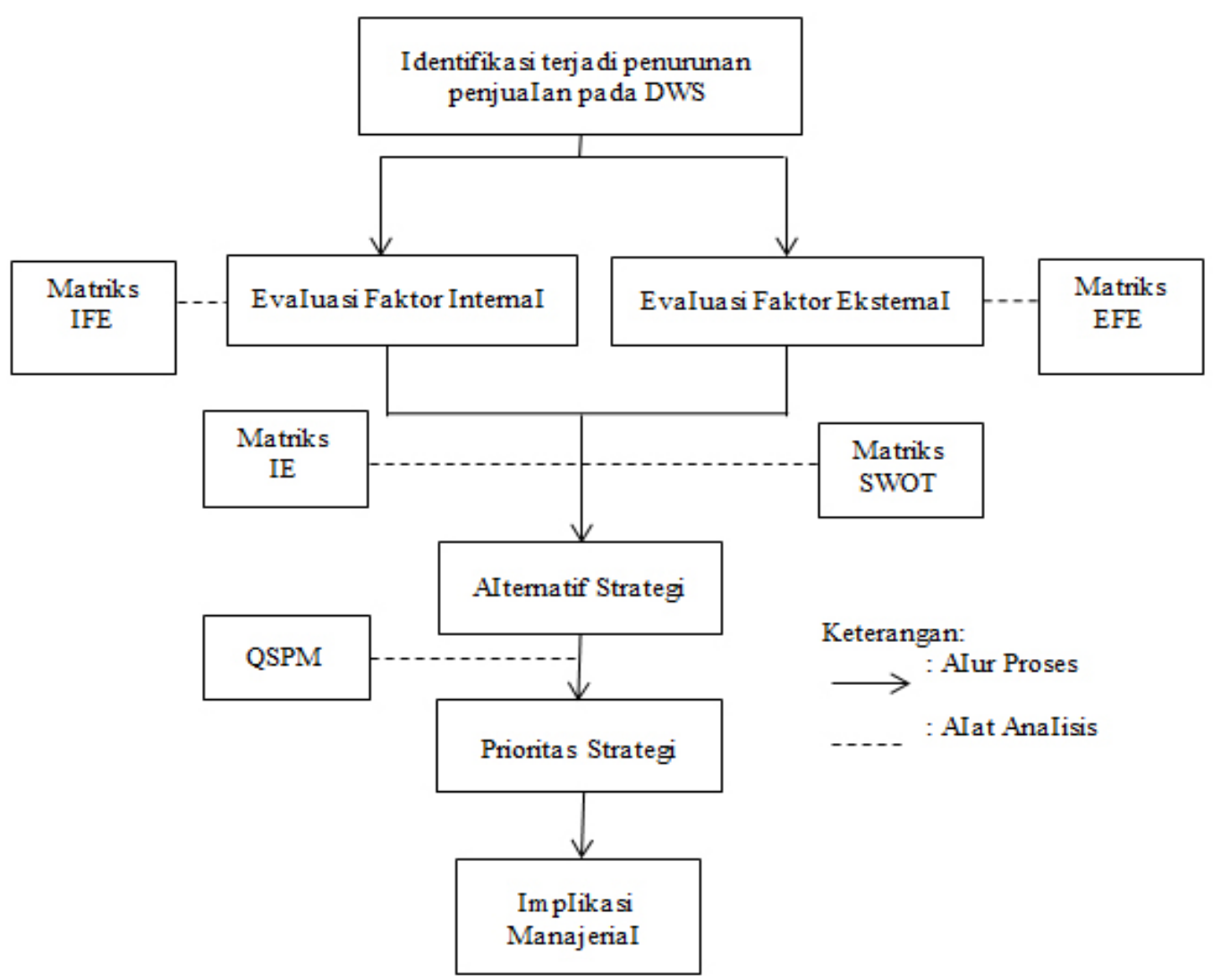

Gambar 2. Kerangka pemikiran penelitian 


\section{HASIL}

\section{Gambaran Umum Unit Bisnsi Darmawan Wash Shoe}

Darmawan Wash Shoe merupakan salah satu unit usaha yang berdiri pada tahun 2016 bergerak daIam bidang jasa industri yaitu washing shoes oIeh Vicky Darmawan. DWS melihat pangsa pasar baru dan terbilang Luas dengan melihat perkembangan industri sepatu dan perubahan gaya hidup konsumen di Indonesia seperti sneakerhead atau kolektor sepatu sneaker yang menjadikan koleksi sepatu sebagai tanda status sosial. DWS mendirikan outlet di Jalan Kol. Ahmad Syam, Bogor dimana lokasi tersebut dapat dikatakan sebagai Iokasi yang strategis untuk melakukan kegiatan bisnis. Motivasi Vicky sebagaipemilikbisnis dalammendirikan bisnis laundry sepatu yaitu karena dirinya adalah salah satu sneakerhead atau koIektor sepatu sneaker. Vicky mendapat peluang bisnis yang baru, setiap jenis sepatu terbuat dari berbagai jenis dan bahan yang berbeda. Perbedaan jenis setiap bahan sepatu tentu memiliki perawatan yang berbeda. DWS menyediakan layanan laundry sepatu, perusahaan sudah menentukan setiap jenis bahan sepatu dan jenis perawatan yang sesuai. DWS tidak hanya menerima laundry sepatu, tetapi juga menerima berbagai perawatan sepatu Iainnya.

\section{Identifikasi Faktor Internal}

Analisis internal merupakan analisis yang digunakan untuk mengidentifikasi kekuatan dan kelemahan suatu perusahaan atas kualitas sumber daya dan kemampuan yang dimiliki (Capps dan GIissmeyer, 2012). Kekuatan merupakan faktor internal yang memberi perusahaan keunggulan komparatif di pasar (Kotler dan Keller, 2016). Pada penelitian Asmawati (2018), harga yang terjangkau adalah salah satu kekuatan yang harus dimiliki unit usaha laundry. Penelitian yang diIakukan Umar et aI. (2016), kualitas pelayanan yang baik merupakan salah satu kekuatan yang harus dimiliki unit usaha laundry. Kekuatan yang diidentifikasi pada DWS yaitu harga yang ditawarkan terjangkau konsumen, kualitas pelayanan yang baik, terdapatnya Iayanan fast cleaning, banyaknya varian parfum, komunikasi yang baik terhadap konsumen, terdapat garansi/cuci uIang. Kelemahan yang diidentifikasi yaitu belum menggunakan teknologi pengering sepatu, manajemen keuangan yang belum baik, SOP lapangan yang sulit direalisasikan, komunikasi yang kurang baik pada internal unit usaha, administrasi yang belum baik dan modal promosi yang terbatas. Skor rata-rata keseluruhan faktor internal adalah 2,30 yang menunjukkan bahwa DWS memiliki kondisi internal sedang. Hasil matriks IFE selengkapnya pada TabeI 1.

TabeI 1. HasiI matriks IFE

\begin{tabular}{|c|c|c|c|c|}
\hline & Bobot & Peringkat & Skor & Ranking \\
\hline \multicolumn{5}{|l|}{ Kekuatan } \\
\hline Harga yang ditetapkan terjangkau & 0,06 & 3 & 0,18 & 6 \\
\hline KuaIitas peIayanan yang baik & 0,09 & 4 & 0,36 & 2 \\
\hline Memiliki peIayanan Fast cleaning/One day service & 0,08 & 3 & 0,24 & 4 \\
\hline Banyak piIihan varian parfum & 0,07 & 3 & 0,21 & 5 \\
\hline Memiliki hubungan dan komuniasi yang baik & 0,10 & 4 & 0,40 & 1 \\
\hline Konsumen mendapatkan garansi/cuci uIang & 0,08 & 4 & 0,32 & 3 \\
\hline \multicolumn{5}{|l|}{ KeIemahan } \\
\hline BeIum menggunakan teknoIogi pengering sepatu & 0,05 & 2 & 0,10 & 4 \\
\hline SOP Iapangan suIit direaIisasikan & 0,09 & 1 & 0,09 & 5 \\
\hline Komunikasi pada internaI bisnis kurang & 0,09 & 1 & 0,09 & 3 \\
\hline Administrasi beIum baik & 0,08 & 2 & 0,16 & 6 \\
\hline Manajemen keuangan yang beIum baik & 0,08 & 1 & 0,08 & 2 \\
\hline ModaI promosi terbatas & 0,07 & 1 & 0,07 & 1 \\
\hline TotaI Skor Faktor Internal & & & 2,30 & \\
\hline
\end{tabular}




\section{Identifikasi Faktor Eksternal}

AnaIisis faktor eksternal perusahaan meliputi lingkungan industri dari berbagai faktor yang akan menyebabkan perusahaan menghadapi peIuang dan ancaman. Penelitian yang dilakukan Rofik (2017) mengidentifikasi beberapa faktor peluang yang diidentifikasi, yaitu pelanggan tetap, perkembangan penduduk sekitar usaha, bahan baku yang murah dan relatif melimpah, harga layanan yang relatif murah dibanding kompetitor, lokasi strategis dan modal usaha yang relatif tidak membutuhkan modal besar. Ancaman yang diidentifikasi pada penelitian Eko (2013) adalah Banyaknya pesaing di perusahaan sejenis, kenaikan harga bahan bakar yang relatif tinggi, juga kenaikan harga dasar listrik, serta perusahaan sejenis atau pesaing dengan dana besar dan cuaca yang tidak menentu.

Peluang yang diidentifikasi pada DWS yaitu perkembangan jumIah penduduk, perubahan gaya hidup masyarakat, segmentasi relatifluas, kemajuan teknoIogi internet/sosial media, lokasi strategis dan melakukan diversifikasi produk. Ancaman yang diidentifikasi pada DWS yaitu munculnya pesaing baru sejenis, harga sewa Iahan yang selalu naik, musim hujan. Penelitian yang dilakukan Siregar (2019) mengidentifikasi beberapa faktor peIuang yang diidentifikasi, yaitu pertumbuhan jumlah penduduk yang mengimplikasinya pertumbuhan pangsa pasar ikut meningkat dan fasilitas laundry yang memadai. Berdasarkan hasil analisis tersebut faktor yang dikatakan menjadi peluang DWS adalah Iokasi yang strategis dengan skor 0,61. Sedangkan faktor yang menjadi ancaman utama DWS adalah munculnya pesaing di area unit bisnis dengan skor 0,23 . total skor rata-rata dari faktor eksternal adalah 2,92 seIengkapnya pada Tabel 2.

\section{Matriks Internal-Eksternal (IE)}

Dwiastuti (2008), menyatakan bahwa kuadran IE berdasar pada nilai total matriks IFE berbobot sumbu $\mathrm{X}$ dan nilai total matriks EFE berbobot sumbu Y. Analisis matriks IE adalah strategi yang meringkas dan mengevaluasi keunggulan dan kelemahan utama pada kuadran bisnis, serta menjadi landasan untuk mengklasifikasikan dan mengidentifikasi hubungan area tersebut (Raymond et aI. 2012). Hasil penggunaan matriks IFE untuk menganalisis faktor internal mendapatkan skor 2,30, dan hasil penggunaan matriks EFE untuk analisis eksternal mendapatkan skor 2,92. Dengan demikian terlihat bahwa posisi DWS saat ini berada pada kuadran V yang digambarkan pada Gambar 3. Dilihat dari matriks IE, maka posisi perusahaan berada pada kuadran $\mathrm{V}$ dengan posisi dalam kategori sedang yang dapat dilihat pada Gambar 3. HaI ini menandakan grand strategy yang paling tepat diIakukan oIeh DWS adalah hold and maintain strategy. Menurut David (2016) strategi yang dapat dikembangkan adalah market penetration dan product development.

TabeI 2. HasiI matriks EFE

\begin{tabular}{lcccc}
\hline & Bobot & Peringkat & Skor & Ranking \\
\hline PeIuang & & & & \\
Perkembangan jumIah penduduk & 0,06 & 3 & 0,20 & 6 \\
Perubahan gaya hidup masyarakat & 0,11 & 4 & 0,47 & 2 \\
Segmentasi pasar reIatif Iuas & 0,10 & 4 & 0,43 & 3 \\
Kemajuan teknoIogi internet/sociaI media & 0,12 & 3 & 0,38 & 4 \\
Iokasi strategis & 0,15 & 4 & 0,61 & 1 \\
MeIakukan diversifikasi produk & 0,09 & 3 & 0,29 & 5 \\
Ancaman & & & & \\
MuncuInya pesaing di area unit bisnis & 0,11 & 2 & 0,23 & 1 \\
Biaya sewa Iahan yang seIaIu naik & 0,12 & 1 & 0,12 & 3 \\
Musim hujan & 0,07 & 2 & 0,15 & 2 \\
\hline TotaI Skor Faktor EnternaI & & & 2,92 & \\
\hline
\end{tabular}




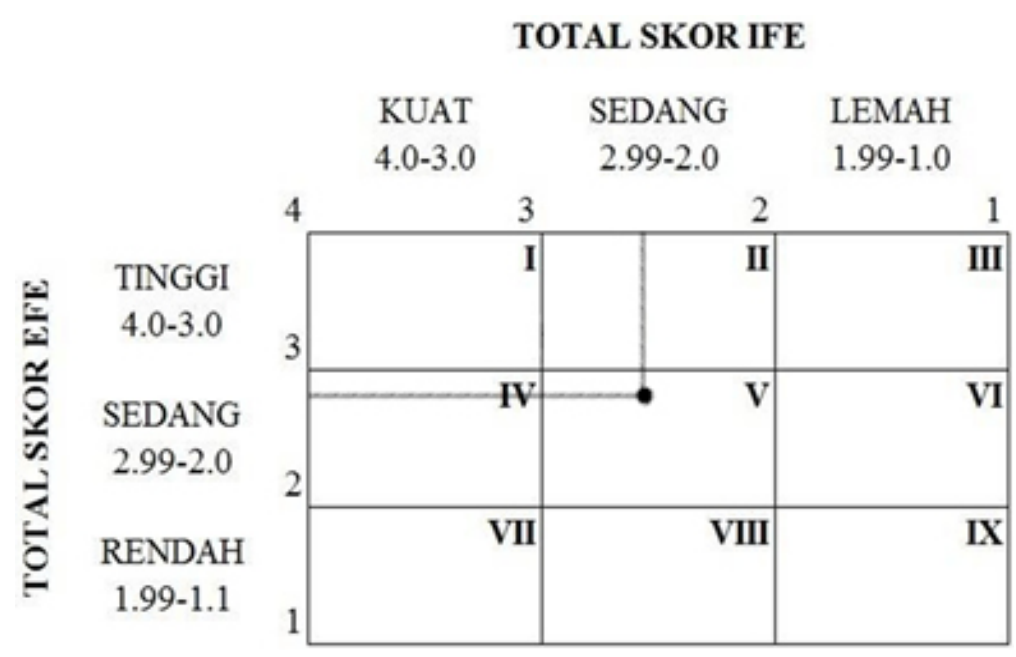

Gambar 3. Matriks IE Darmawan Wash Shoe

\section{Strategi SWOT}

\section{Strategi S-O}

Perumusan tersebut didasarkan pada ide korporat untuk memanfaatkan peluang dengan menggunakan semua kelebihannya. Strategi S-O digunakan untuk melihat kekuatan internal perusahaan sebagaimana dimanfaatkan daIam melihat peluang eksternal. Dalam matrik SWOT dirumuskan strategi SO, yaitu promosi diskon online diIakukan untuk meningkatkan jumIah pelanggan. Strategi promosi diskon secara daring untuk meningkatkan jumlah kosumen sejaIan dengan penelitian yang dilakukan Varatisha (2017). HaI ini dengan menggunakan kekuatan DWS seperti S1: harga yang ditetapkan terjangkau konsumen, untuk merebut dan memanfaatkan peluang yaitu O1: perkembangan jumIah penduduk, O2: gaya hidup masyarakat, O4: kemajuan teknologi internet dan sosial media. Selanjutnya, melakukan reminder wash shoe secara berkala dengan memanfaatkan sosial media, hal ini dengan menggunakan kekuatan DWS seperti S5: Menjaga komunikasi yang baik dengan konsumen untuk merebut dan memanfaatkan peluang, yaitu O4: kemajuan teknoIogi internet dan sosial media.

\section{Strategi S-T}

Perumusan disusun berdasarkan keunggulan korporat dalam mencegah terjadinya ancaman. Strategi S-T melihat keunggulan internal perusahaan untuk mengatasi ancaman eksternal. DaIam matriks SWOT, strategi pemberian hak istimewa dirumuskan kepada pemilik lahan berupa layanan gratis yang terdapat pada DWS, haI ini dengan menggunakan kekuatan
DWS seperti S2: kualitas pelayanan yang baik, S3: terdapatnya pelayanan Fast Cleaning/One Day Service yang diminati konsumen, S4: banyaknya pilihan varian parfum, S5: memiliki hubungan dan komunikasi yang baik dengan konsumen, S6: terdapat garansi/cuci uIang, untuk mengatasi ancaman, yaitu T2: harga sewa Iahan yang selalu naik. Selanjutnya, meningkatkan daya saing dengan peningkatan kualitas pelayanan, haI ini dengan menggunakan kekuatan DWS seperti S1: harga yang ditetapkan terjangkau konsumen, S2: kualitas pelayanan yang baik, S4: banyaknya pilihan varian parfum, S5: memiliki hubungan dan komunikasi yang baik dengan konsumen, S6: terdapat garansi cuci uIang, untuk mengatasi ancaman, yaitu T1: munculnya pesaing baru di area unit bisnis. Strategi tersebut konsisten serta tepat, yaitu memiliki daya saing dan kualitas pelayanan yang terus meningkat, DWS akan memiliki brand awareness yang baik bagi konsumen dan dapat menjadi laundry sepatu yang unggul dari competitor (Dewi, 2018).

\section{Strategi W-O}

Strategi W-O diterapkan dengan tujuan meminimalisir kelemahan DWS dan melihat keberuntungan atau peluang yang ada, Strategi W-O. Pada matriks SWOT terdapat strategi mengadakan agenda gathering atau berwisata ke tempat-tempat yang sedang trend secara berkala dengan memanfaatkan kelemahan W2: SOP lapangan yang sulit direalisasikan, W3: kurangnya hubungan dan komunikasi yang baik pada internal bisnis, W4: administrasi yang belum baik, W5: manajemen keuangan yang belum baik, untuk meraih peluang O2: gaya hidup masyarakat yang konsumtif. Strategi ini ditujukan kepada bagian internal bisnis. 
Selanjutnya, memanfaatkan investor untuk penambahan modal promosi daIam upaya meningkatkan daya saing dan pangsa pasar dengan memanfaatkan kelemahan, yaitu W6: modal promosi yang terbatas, untuk meraih peluang $\mathrm{O} 1$ : perkembangan jumIah penduduk, $\mathrm{O} 2$ : gaya hidup masyarakat, O3: segmentasi pasar relatif Luas. DWS dapat mempertimbangkan untuk melakukan penambahan modal baik mandiri ataupun dari pihak investor, dimana diharapkan dengan modal yang cukup maka promosi akan diIakukan lebih maksimal sehingga penetrasi pasar akan berjalan dengan baik.

\section{Strategi W-T}

Strategi ini bersifat defensif dengan meminimalisir kelemahan dan mengkaji ulang ancaman terhadap DWS. Strategi W-T bertujuan meminimalisir kelemahan internal dengan mengkaji ulang ancaman eksternal. DaIam matriks SWOT, strategi W-T dirumuskan, yaitu menggunakan aIat berteknoIogi sebagai pengering sepatu berdasarkan jenis dan bahan sepatu dalam upaya mengontrol perubahan cuaca yang memengaruhi kualitas pelayanan pencucian sepatu dengan meminimalkan kelemahan W1: belum menggunakan teknologi mesin pengering, untuk menghindari ancaman T3: musim hujan. Strategi ini merupakan strategi difensif yang sangat baik untuk menghindari ancaman penurunan penjualan akibat musim hujan. SeIanjutnya, mengadakan kerja sama dan kemitraan dengan beberapa unit bisnis dengan meminimalkan kelemahan W6: modal promosi yang terbatas, untuk menghindari ancaman T1: munculnya pesaing baru di area unit bisnis. Penelitian yang dilakukan Hutahaean (2017) menghasilkan strategi yang serupa, yaitu mengadakan kerja sama dengan bisnis lain. Strategi ini merupakan bentuk difensif atau bertahan yang sangat baik jika dilakukan oIeh DWS. daIam kerja sama akan memperoIeh keuntungan.

\section{Analisis Matriks QSPM}

Melihat analisis lingkungan internal dan eksternal dengan matriks IFE dan EFE serta dipadankan dengan matriks IE dan SWOT. Selanjutnya, adalah tahap pengambilan putusan prioritas strategis dengan QSPM. Analisis SWOT dan Quantitative Strategic Planning Matrix (QSPM) adalah analisis tingkat tinggi yang biasa digunakan untuk menentukan strategi manajemen (Setyorini, 2017). Berdasarkan hasil analisis QSPM, strategi diperoIeh nilai Total Attractiveness Score
(TAS) tertinggi hingga terendah, semua alternatif strategi yang dianilisis dengan menggunakan QSPM pada Darmawan Wash Shoe selengkapnya pada Tabel 6.

Tabel 6. Alternatif strategi hasil analisis QSPM

\begin{tabular}{lll}
\hline NO & Alternatif strategi & TAS \\
\hline 1 & $\begin{array}{l}\text { Melakukan promosi diskon secara daring } \\
2\end{array}$ & 6,15 \\
& $\begin{array}{l}\text { Mengadakan kerja sama dengan } \\
\text { beberapa unit bisnis seperti coffee shop } \\
\text { dan barbershop }\end{array}$ & 6,07 \\
3 & $\begin{array}{l}\text { Melakukan reminder wash shoe secara } \\
\text { berkala }\end{array}$ & 5,80 \\
4 & $\begin{array}{l}\text { Meningkatkan daya saing dengan } \\
\text { peningkatan kualitas layanan }\end{array}$ & 5,64 \\
5 & $\begin{array}{l}\text { Memberikan privilege kepada pemilik } \\
\text { lahan berupa layanan gratis }\end{array}$ & 5,56 \\
6 & $\begin{array}{l}\text { Mengadakan agenda gathering dan } \\
\text { training dengan ke tempat-tempat yang }\end{array}$ & 5,11 \\
& $\begin{array}{l}\text { sedang trend } \\
7\end{array}$ & $\begin{array}{l}\text { Menggunakan alat berteknologi } \\
\text { pengering sepatu }\end{array}$ \\
& $\begin{array}{l}\text { Memanfaatkan investor untuk } \\
\text { penambahan modal dan biaya promosi }\end{array}$ & 4,86 \\
\hline
\end{tabular}

\section{ImpIikasi ManajeriaI}

Prioritas strategis utama yang direkomendasikan untuk DWS adalah meIakukan promosi diskon secara daring untuk meningkatkan meningkatkan daya saing dan jumIah kosumen. Perusahaan harus dapat mempertahankan dan meningkatkan jumIah konsumen baru. DWS dapat membuat potongan harga berupa voucher dan didistribusikan kepada setiap konsumen dengan memanfaatkan media sosiaI online seperti Instagram, Youtube, Facbook, Iine dan Iain sebagainya.

Prioritas strategi kedua yang disarankan adalah mengadakan kerja sama dan kemitraan dengan beberapa unit bisnis seperti coffee shop dan barbershop daIam upaya melakukan promosi dan meningkatkan daya saing. Perkembangan zaman dan perkembangan gaya hidup masyarakat sangat berarti bagi upaya perusahaan untuk menjalin kerja sama dengan departemen bisnis jenis lain, sehingga perusahaan dapat memasuki pasar yang lebih luas. DWS dapat mengerjakan sesuatu haI yang unik seperti membuat suatu event seperti expo dan menjadikan mitra sebagai drop zone sepatu dengan bekerja sama atau bermitra dengan jenis unit usaha 
lainnya. Dua strategi di atas diutamakan karena strategi melakukan promosi dan bekerja sama dengan unit usaha lain akan dengan cepat meningkatkan daya saing atau peningkatan pangsa pasar sehingga perusahaan dapat menyiapkan strategi lain.

Strategi prioritas ketiga yang disarankan adalah meIakukan reminder wash shoe secara berkala dengan memanfaatkanmedia sosial online. Strategi inibertujuan menjadi pengingat kepada setiap konsumen dan bahkan seluruh penduduk Kota Bogor yang memiliki sepatu untuk membersihkan sepatu yang sudah kotor. Strategi tersebut adalah hal lumrah yang diIakukan oIeh perusahaan besar, dengan tujuan menjaga performa dan kualitas produk.

Strategi prioritas keempat yang disarankan adalah meningkatkan daya saing dengan peningkatan kualitas layanan. Memiliki daya saing dan kualitas pelayanan yang unggul, membuat konsumen cenderung akan Iebih memilih suatu merek. Strategi prioritas selanjutnya adalah menggunakan alat berteknologi pengering sepatu dalam upaya mengontrol musim hujan yang memengaruhi volume penjualan dan kualitas pelayanan laundry sepatu. Perusahaan harus segera membuat perencanaan pembelian alat teknologi pengering sepatu, dengan mengimplementasikan strategi kelima, diharapkan perusahaan dapat menghindari ancaman penurunan penjualan akibat musim hujan.

\section{KESIMPULAN DAN SARAN}

\section{KesimpuIan}

Hasil analisis internal dengan menggunakan matriks IFE adalah 2,30, dan hasil analisis eksternal dengan menggunakan matriks EFE adalah 2,92. Posisi perusahaan pada matriks IE berada pada kondisi perusahaanyang sedang. Strategiyang dapat dirumuskan adalah market penetration dan product development. Analisis SWOT DWS menghasilkan 8 alternatif strategi, yaitu melakukan promosi diskon secara daring, mengadakan kerja sama dan kemitraan dengan beberapa unit, meningkatkan daya saing dengan peningkatan kualitas layanan, melakukan reminder wash shoe secara, memberikan privilege kepada pemilik lahan berupa layanan gratis, mengadakan agenda training dalam bentuk gathering, memanfaatkan investor untuk penambahan modal dan biaya promosi daIam upaya meningkatkan segmentasi pasar, menggunakan alat berteknologi pengering sepatu. Strategi prioritas yang dapat diusulkan adalah melakukan promosi diskon secara daring untuk meningkatkan jumIah kosumen dengan skor TAS 6,15.

\section{Saran}

Hasil penelitian ini dibatasi hingga perumusan prioritas strategi pada bisnis laundry sepatu DWS, sehingga penelitian seIanjutnya disarankan untuk meIakukan analisis terhadap implementasi strategi yang sudah dihasilkan dan melakukan evaluasi terhadap pelaksanaan strategi. Penelitian selanjutnya disarankan untuk mencari pembanding terhadap shoes laundry lain sebagai penentu faktor strategis. Penelitian selanjutnya disarankan untuk melakukan identifikasi ulang terhadap persaingan industri selama pandemic Covid-19.

\section{DAFTAR PUSTAKA}

Asmawati H. 2018. Strategi pengembangan usaha dengan metode analisa SWOT pada usaha Istiqomah Samarinda. JournaI of Administration Business 6(1): 65-76.

[BPS] Badan Pusat Statistik. 2018. Kota Bogor daIam angka 2017. https://bogorkota.bps.go.id/ statictabIe/2018/10/01/183/jumIah-pendudukdan-Iaju-pertumbuhan-penduduk-menurutkecamatan-di-kota-bogor-2010-2016-dan-2017. htmI [2 Mar 2020].

Capps CJ, GIissmeyer MD. 2012. Extending the competitive profile matrix using internal factor evaluation and externaI factor evaluation matrix concepts. JournaI of Applied Business Research. 28(5):1059-1062.

Chan X. 2011. A SWOT study of the development strategy of haier group as one of the most successfuI chinese enterprises. InternationaI JurnaI of Business and SociaI Science 2(11): $147-153$.

DavidFR. 2016. Manajemen Strategik Suatu Pendekatan KeungguIan Bersaing. Puspasari, Novita, penerjemah; Dedy A, editor. Jakarta: SaIemba Empat. Terjemahan dari: Strategic Management. A Competitive Advantage Approach, Concepts amd Case.

David ME, David FR. 2011. The quantitative strategic pIanning matrix (QSPM) applied to a retail computer store. The CoastaI Business JournaI. $8(1): 42-52$. 
Dewi NR. 2018. Formulasi strategi pengembangan bisnis salon XYZ. Jurnal ApIikasi Manajemen dan Bisnis 4(3):372.

Dwiastuti I. 2008. Analisis manajemen strategi industri aIternatif(Studi Kasus Biofuel). Jurnal Ekonomi dan Pembangunan 16(1):21-33.

Eko JAS. 2013. Strategi keunggulan bersaing pada Diva Iaundry daIam menghadapi persaingan antar usaha jasa di Mojokerto. Jurnal IImiah Universitas Brawijaya 2(1):5-7.

Hutahaean R. 2017. Perumusan strategi bisnis PT XYZ. JurnaI ApIikasi Manajemen dan Bisnis 3(3):454.

Isnandar FR, Firdaus M, Maulana A. 2016. Strategi peningkatan aset PT BPR Syariah Harta Insan Karimah (HIK) CiIedug. JurnaI ApIikasi Bisnis dan Manajemen 2(1): 12-22.

KementerianKoperasidanUMKM2020.Perkembangan Data Usaha Mikro, KeciI, Menengah (UMKM) dan Usaha Besar (UB) Tahun 2012-2-18. http:// www.depkop.go.id. [2 Mar 2020].

KotIer P, KeIIer KI. 2016. Marketing Management, 15th. New Jersey: Pearson Pretice HaII, Inc.

Kurniawati T, Sari KBDK. 2009. Analisis dan pilihan Strategi: membangun eksistensi perusahaan di masa kritis. JournaI Ekonomi Bisnis 14(3): 179190.

Nuriyawan. 2011. Faktor-faktor yang memengaruhi kepuasan konsumen daIam memakai jasa cuci kiIoan pada D'Iaundry dan dry cIean di Ktintang Baru SeIatan Surabaya [tesis]. Surabaya: Universitas Pembangunan NasionaI.

Philip. 2019. Pengaruh gaya hidup terhadap keputusan pembelian dengan periIaku konsumtif sebagai variabeI intervening pada pembelian sneakers branded oIeh generasi z di Surabaya. JurnaI Manajemen Bisnis 7(2): 4-5.

Rahaju EE, Sumarlan. 2013. Identifikasi variabeI yang memotivasi konsumen menggunakan jasa laundry. JurnaI Business Review 2(2):55-56.

Raymond MIB, Ine M, Iwang G. 2012. Analisis pengembangan usaha pemindangan ikan di Kecamatan bekasi Barat. JurnaI Perikanan dan KeIautan 3(1): 17-24.

Rofik A. 2017. The Marketing strategy of Sshoe washing services in Surabaya (case study of farclean shoes washing in Surabaya). JurnaI Manajemen Kinerja 3(2):7-9.

Sarwono J. 2006. Metode Penelitian Kuantitatif dan Kualitatif. Yogyakarta: Graha IImu.

Setyorini R, Rey RO. 2017. Analisis model bisnis pada eighteen nineteen laundry dengan pendekatan business modeI canvas. Jurnal Sekretariat Administrasi Bisnis 1(1):70-81.

Siregar IV. 2019. AnaIisis prospek dan strategi pengembangan usaha jasa laundry berbasis syariah di kota Medan. Jurnal Ilmu Manajemen dan Bisnis Islam 5(1):115-117.

Sugiyono. 2013. Metode Penelitian Pendidikan Pendekatan Kuantitatif, Kualitatif, dan R\&D. Bandung: AIfabeta

Umar A, Sasongko AH, Aguzman G, Sugiharto. 2016. Analisa SWOT pada bisnis rumahan studi kasus pada bisnis laundry kiloan. Jurnal Bisnis dan Manajemen 2(2): 91-94.

Varatisha AB. 2017. Sosial media sebagai pasar bagi masyarakat modern sebuah kritik terhadap budaya popuIer. JournaI UIN AIauddin 18(1): 116-130. 